\title{
KESIAPSIAGAAN TENAGA KESEHATAN PUSKESMAS DALAM PENANGGULANGAN BENCANA BANJIR DI KECAMATAN MANGGALA KOTA MAKASSAR TAHUN 2019
}

\author{
Health Workers Public Health Center Preparedness Factors In Flood Disaster \\ Management In Manggala District Makassar City In 2019
}

\author{
${ }^{1}$ Herman Bakri, ${ }^{2}$ Syafri K. Arif, ${ }^{3} \mathrm{Hisbullah}$ \\ ${ }^{1}$ Pascasarjana Universitas Hasanuddin, Makassar \\ ${ }^{2}$ Rumah Sakit Universitas Hasanuddin, Makassar \\ ${ }^{3}$ Rumah Sakit Pelamonia, Makassar
}

Email Korespondensi: hermanbakri@pasca.unhas.ac.id

(Hp: 0811410723)

\begin{abstract}
ABSTRAK
Indonesia terletak pada wilayah yang rawan terhadap bencana banjir. Kondisi tersebut menuntut kesiapsiagaan dari tenaga kesehatan untuk kegiatan penanggulangan bencana banjir. Penelitian ini bertujuan untuk mengetahui gambaran kesiapsiagaan tenaga kesehatan puskesmas di dalam penanggulangan bencana banjir dan beberapa faktor yang berhubungan dengan kesiapsiagaan tenaga kesehatan puskesmas. Jenis penelitian pada penelitian ini merupakan penelitian analitik dengan pendekatan Cross Sectional Study dengan jumlah sampel sebanyak 40 orang. Hasil analisis terlihat tidak semuanya menyatakan siap siaga dalam penanggulangan bencana banjir. Dari 40 orang responden ternyata masih ada $7,5 \%$ yang menyatakan tidak siap siaga. Hasil dari analisis multivariat menunjukkan bahwa variabel protap/pedoman dan pelaksanaan evaluasi mempunyai pengaruh yang sama terhadap kesiapsiagaan tenaga kesehatan puskesmas yaitu protap/pedoman bencana dengan nilai $\operatorname{OR}(\operatorname{EXP}(B))=0,889$ dan pelaksanaan evaluasi dengan nilai $\operatorname{OR}(\operatorname{EXP}(B))=0,889$.
\end{abstract}

Kata Kunci : Bencana Banjir, Kesiapsiagaan Bencana, Tenaga Kesehatan Puskesmas

\section{ABSTRACT}

Indonesia is located in an area prone to floods. Makassar is one of the regions that is definitely experiencing flood. These conditions require the preparedness of the medical practitioner for the activities of flood management. This study aims at finding an overview of flood management and several factors related to the preparedness of the medical practitioner of community health center in Manggala. This study includes an analytical research using a Cross Sectional Study approach with a total sample of 40 people from all community health center in Manggala. The analysis results showed that not all of the medical practitioner of community health center stated that they were ready for flood management. Out of 40 respondents, it turns out that there were still $7.5 \%$ saying they were not ready. The results of the multivariate analysis showed that the variable of Standard Operating procedure/guideline and the implementation of the evaluation had the same effect on the preparedness of the medical practitioner of community health center, which are the variable of Standard Operating procedure/guideline with the value of $O R\{\operatorname{EXP}(B)\}=0.889$ and the implementation of the evaluation with the value of $O R\{E X P(B)\}=0.889$.

Keywords: Flood, Disaster Preparedness, Medical Practitioner of Community Health center

\section{PENDAHULUAN}

Indonesia berada dipertemuan tiga lempeng tektonik. Indonesia juga terletak pada wilayah yang rawan terhadap bencana alam baik yang berupa tanah longsor, gempa bumi, letusan gunung berapi, tsunami, banjir, dan lain-lain. Indonesia menjadi salah satu negara yang paling rentan bencana.

Kota Makassar yang merupakan ibukota Provinsi Sulawesi Selatan tidak luput dari bencana banjir yang menimbulkan masalah kesehatan. Berdasarkan Indeks Ratio Bencana Indonesia (IRBI) tahun 2013, kota Makassar merupakan salah satu daerah di Sulawesi Selatan yang mempunyai indek risiko bencana tinggi. Menurut Badan Penanggulangan Bencana Daerah (BPBD) kota Makassar, wilayah dengan ancaman banjir paling tinggi adalah wilayah Kecamatan Manggala. Tahun 2018 terjadi banjir yang mengakibatkan warga mengungsi. Jumlah pengungsi mencapai 9.328 jiwa dari total 2.841 kepala keluarga. Selain masalah pengungsi, banjir juga mengakibatkan rusaknya fasilitas umum yang ada diwilayah tersebut,

Oleh karena kejadian bencana sering kali datang mendadak dan diluar jam kerja rutin. Kondisi tersebut menuntut kesiapsiagaan dari tenaga kesehatan untuk selalu siap bersedia bekerja diluar jam kerja 
rutin dengan perintah atasan yang datang secara mendadak serta bersedia bekerja dengan sarana dan biaya operasional yang tersedia diunit kerja untuk kegiatan penanggulangan bencana banjir.

\section{METODE PENELITIAN Lokasi dan Jenis penelitian}

Penelitian dilakukan di seluruh puskesmas yang ada di kecamatan Manggala kota Makassar yaitu Puskesmas Antang Raya, Puskesmas Antang Perumnas, Puskesmas Tamangngapa, Dan Puskesmas Bangkala. Jenis penelitian pada penelitian ini merupakan penelitian analitik dengan pendekatan Cross Sectional Study. Penelitian ini menjelaskan tentang faktorfaktor yang berhubungan dengan kesiapsiagaan tenaga kesehatan puskesmas yang ada di wilayah kecamatan Manggala yaitu Puskesmas Antang Perumnas, Puskesmas Antang Raya, Puskesmas Bangkala, dan Puskesmas Tamangngapa.

\section{Populasi dan sampel}

Populasi adalah wilayah generalisasi yang terdiri atas objek/subjek yang mempunyai kualitas dan karakteristik tertentu yang ditetapkan oleh peneliti untuk dipelajari dan ditarik kesimpulannya. Sampel pada penelitian ini diambil dengan cara exhaustive sampling (total sampling). Populasi dan sampel dari penelitian ini yaitu tenaga kesehatan yang tergabung dalam Tim Siaga Bencana ditiap puskesmas dengan pembagian Puskesmas Antang Perumnas sebanyak 10 orang, Puskesmas Antang Raya sebanyak 10 orang, Puskesmas Bangkala sebanyak 10 orang, Puskesmas Tamangngapa 10 orang.

\section{Metode pengumpulan data}

Pengambilan data dilakukan dengan cara pengisian kuisioner yang dilakukan oleh tenaga kesehatan yang bertugas sebagai tim penanggulangan bencana pada ke empat puskesmas.

\section{Analisis Data}

Metode analisis data dilakukan dengan dilakukan dengan analisis kuantitatif. Analisis univariat digunakan untuk menggambarkan distribusi variabel yang diukur dalam penelitian dengan cara mendeskripsikannya dan dinyatakan dalam bentuk tabel proporsi. Dalam analisis bivariat digunakan uji chi square atau uji beda proporsi, karena data yang digunakan berbentuk kategorik. Analisis ini digunakan untuk melihat ada tidaknya hubungan antara dua variabel dan kemaknaannya dilihat dari nilai $p<0,05$ (Hastono dan Sabri, 2008). Pada analisis multivariat, diajukan uji secara bersama-sama sehingga dapat dilihat variabel mana yang paling berpengaruh terhadap kesiapsiagaan tenaga kesehatan. Variabel yang diikutkan dalam analisis multivariat adalah variabel yang mempunyai nilai $p<0,25$ dalam analisis bivariat. Analisis multivariat dilakukan untuk menganalisis dan memperkirakan faktor-faktor yang dominan dengan variabel terikat melalui variabel bebas secara bersama-sama dengan menggunakan Uji regresi logistik pada tingkat kepercayaan 95\%. Analisis multivariat dilakukan untuk menganalisis dan meramalkan hubungan antara variabel dependen dalam hal ini kesiapsiagaan tenaga kesehatan dengan sekelompok variabel independen secara bersamasama.

\section{HASIL}

\section{Analisis univariat}

Tabel 5.1 menunjukkan gambaran kesiapsiagaan tenaga kesehatan puskesmas di kecamatan Manggala kota Makassar sebagian besar menyatakan siap siaga dalam penanggulangan bencana banjir yaitu sebanyak 37 orang $(92,5 \%)$ dan 3 orang $(7,5 \%)$ menyatakan tidak siap siaga. Tabel 5.2 terlihat gambaran umur responden bahwa sebagian besar responden berumur $35-60$ tahun yaitu 29 orang $(72,5 \%)$ dan 11 orang $(27,5 \%)$ yang berumur $19-34$ tahun. Tabel 5.3 terlihat gambaran jenis kelamin bahwa sebagian besar responden berjenis kelamin perempuan yaitu sebanyak 34 orang $(85 \%)$ dan laki-laki sebanyak 6 orang $(15 \%)$. Tabel 5.4 terlihat gambaran pengalaman kerja responden bahwa sebagian besar $(67,5 \%)$ mempunyai pengalaman kerja selama 6-15 tahun, kemudian $>16$ tahun sebanyak $30 \%$ dan < 5 tahun sebanyak 2,5\%. Pada tabel 5.5 terlihat gambaran frekuensi pelatihan bencana yang pernah diikuti oleh responden menunjukkan bahwa sebagian besar 30 orang $(75 \%)$ tidak pernah mengikuti pelatihan dan 10 orang (25\%) pernah mengikuti pelatihan manajemen bencana. Pada tabel 5.6 terlihat gambaran frekuensi gladi/simulasi yang pernah diikuti oleh responden bahwa sebagian besar (62,5\%) menyatakan tidak pernah mengikuti gladi/simulasi dan $37,5 \%$ menyatakan pernah mengikuti gladi/simulasi. Tabel 5.7 terlihat gambaran kecukupan sarana di unit 
kerja menurut responden menunjukkan bahwa sebagian besar (65\%), responden menyatakan cukup dan ada $35 \%$ yang menyatakan tidak cukup. Dari tabel 5.8 terlihat gambaran tersedianya biaya operasional di unit kerja menurut responden menyatakan bahwa sebagian besar $(57,5 \%)$ responden menyatakan tidak tersedia dan ada $42,5 \%$ yang menyatakan tersedia. Pada tabel 5.9 terlihat gambaran ketersediaan kebijakan pemerintah tentang kesiapsiagaan bencana menurut responden menunjukkan bahwa sebagian besar $(65 \%)$ menyatakan tidak tersedia dan ada 35\% responden yang menyatakan tersedia. Dari tabel 5.10 terlihat gambaran ketersediaan protap/pedoman di unit kerja menurut responden menyatakan bahwa sebagian besar $(62,5 \%)$ menyatakan tersedia dan ada $37,5 \%$ responden yang menyatakan tidak tersedia. Dari tabel 5.11 terlihat gambaran pelaksanaan evaluasi kegiatan di unit kerja menurut responden menyatakan bahwa sebagian besar $(62,5 \%)$ responden menyatakan bahwa dilakukan evaluasi dan ada $37,5 \%$ responden yang menyatakan tidak dilakukan evaluasi.

\section{Analisis Bivariat}

Berdasarkan tabel 5.12 dapat dijelaskan

hal-hal berikut ini :

1. Hubungan umur dengan kesiapsiagaan tenaga kesehatan puskesmas

Dari hasil analisis statistik, menunjukkan tidak adanya perbedaan yang bermakna secara statistik dimana $p$ value $=1,230$ atau $p>0,05$.

2. Hubungan jenis kelamin dengan kesiapsiagaan tenaga kesehatan puskesmas

Dari hasil analisis statistik, ternyata menunjukkan tidak adanya perbedaan yang bermakna $(p=0,572$ atau $p>$ $0,05)$.

3. Hubungan lama pengalaman kerja dengan kesiapsiagaan tenaga kesehatan puskesmas

Dari hasil analisis statistik, ternyata menunjukkan tidak adanya perbedaan yang bermakna $(p=0,093$ atau $p>$ $0,05)$.

4. Hubungan frekuensi pelatihan bencana dengan kesiapsiagaan tenaga kesehatan puskesmas.

Dari hasil analisis statistik, ternyata menunjukkan tidak adanya perbedaan yang bermakna proporsi kesiapsiagaan menurut frekuensi pelatihan bencana $(p$ $=1,081$ atau $p>0,05$ ).

5. Hubungan frekuensi simulasi/gladi dengan kesiapsiagaan tenaga kesehatan puskesmas

Dari hasil analisis statistik, ternyata menunjukkan tidak adanya perbedaan yang bermakna $(p=1,177$ atau $p>$ $0,05)$.

6. Hubungan kecukupan sarana dengan kesiapsiagaan tenaga kesehatan puskesmas

Dari hasil analisis statistik, ternyata menunjukkan tidak adanya perbedaan yang bermakna $(p=1,746$ atau $p>$ $0,05)$.

7. Hubungan tersedianya biaya operasional dengan kesiapsiagaan tenaga kesehatan puskesmas

Dari hasil analisi statistik, ternyata menunjukkan tidak adanya perbedaan yang bermakna $(p=2,397$ atau $p>$ $0,05)$.

8. Hubungan tersedianya kebijakan pemerintah tentang kesiapsiagaan bencana dengan tenaga kesehatan puskesmas

Dari hasil analisi statistik, ternyata menunjukkan tidak adanya perbedaan yang bermakna $(p=21,430$ atau $p>$ $0,05)$.

9. Hubungan tersedianya protap/pedoman dengan kesiapsiagaan tenaga kesehatan puskesmas

Dari hasil analisi statistik, ternyata menunjukkan adanya perbedaan yang bermakna $(p=0,024$ atau $p<0,05)$.

10. Hubungan pelaksanaan evaluasi dengan kesiapsiagaan tenaga kesehatan puskesmas

Dari hasil analisi statistik, ternyata menunjukkan adanya perbedaan yang bermakna $(p=0,024$ atau $p<0,05)$.

\section{Analisis multivariat}

Untuk menguji semua variabel independen terhadap variabel dependen maka dilakukan uji logistik regresi (regression logistik).

Berdasarkan hasil analisis bivariat, ternyata ada 2 variabel yang dianalisis keduanya memenuhi syarat untuk dilakukan analisis lebih lanjut dengan analisis multivariat yaitu variabel yang mempunyai signifikansi $(p)<0,025$. Kedua variabel tersebut adalah tersedianya protap/pedoman $(p=0,024)$ dan pelaksanaan evaluasi $(p=0,024)$. 
Selanjutnya untuk menilai hubungan yang paling bermakna diantara kedua variabel independen tersebut terhadap kesiapsiagaan (variabel dependen), maka dilakukan analisis regresi logistik secara bersama-sama semua variabel yang memenuhi syarat

Dari Tabel 5.13 menunjukkan bahwa kedua variabel mempunyai pengaruh yang sama terhadap kesiapsiagaan tenaga kesehatan puskesmas yaitu protap/pedoman bencana dengan nilai OR $($ EXP $(B))=0,889$ dan pelaksanaan evaluasi dengan nilai OR $(\operatorname{EXP}(B))=0,889$. Pembahasan

\section{Gambaran Kesiapsiagaan Tenaga Kesehatan Puskesmas}

Dari 40 orang responden ternyata masih ada $7,5 \%$ yang menyatakan tidak siap siaga. Ketidaksiapsiagaan ini terjadi karena responden tidak bersedia bekerja diluar jam kerja rutin dan atau tidak bersedia bekerja dengan perintah atasan yang datang secara mendadak dan atau tidak bersedia bekerja dengan sarana dan biaya operasional yang tersedia di unit kerja untuk kegiatan penanggulangan bencana banjir diwilayah kerjanya.

\section{Hubungan Umur dengan Kesiapsiagaan Tenaga Kesehatan Puskesmas}

Responden penelitian ini berusia 1934 tahun. Berdasarkan tabel 5.12 tampak bahwa proporsi kesiapsiagaan tenaga kesehatan puskesmas lebih tinggi pada kelompok umur 35-60 tahun (65\%) dibandingkan dengan kelompok umur 19-34 tahun $(27,5 \%)$. Dari hasil analisis statistik untuk melihat hubungan antara umur dengan kesiapsiagaan ternyata tidak menunjukkan adanya perbedaan yang bermakna proporsi kesiapsiagaan menurut kelompok umur tidak bermakna secara statistik dimana $p$ value $=1,230$ atau $p>$ 0,05 .

Gibson (1987), menyatakan bahwa faktor usia merupakan variabel dari individu yang pada dasarnya semakin bertambah usia seseorang akan semakin bertambah kedewasaannya dan semakin banyak menyerap informasi yang akan mempengaruhi produktivitasnya. Teori ini juga dikemukakan oleh Siagian (1995), yang menyatakan bahwa semakin meningkatnya usia seseorang maka kedewasaan, teknik, dan psikologisnya semakin meningkat. la akan mampu mengambil keputusan, semakin bijaksana, semakin mampu berpikir secara rasional, mengendalikan emosi dan toleran terhadap pendapat orang lain.

\section{Hubungan Jenis Kelamin dengan Kesiapsiagaan Tenaga Kesehatan Puskesmas \\ Dari hasil penelitian ini sebagian} besar berjenis kelamin perempuan sebesar $85 \%$. Sedangkan pada jenis kelamin laki-laki proporsinya sebesar $15 \%$. Berdasarkan tabel $\quad 5.12$ tampak bahwa proporsi kesiapsiagaan tenaga kesehatan puskesmas lebih tinggi pada kelompok jenis kelamin perempuan $(77,5 \%)$ dibandingkan dengan kelompok laki-laki (15\%). Dari hasil analisis statistik untuk melihat hubungan antara umur dengan kesiapsiagaan ternyata tidak menunjukkan adanya perbedaan yang bermakna proporsi kesiapsiagaan menurut kelompok jenis kelamin tidak bermakna secara statistik dimana $p$ value $=0,572$ atau $p>0,05$.

Hasil penelitian ini sejalan dengan studi-studi psikologis yang telah menemukan bahwa perempuan lebih bersedia untuk mematuhi wewenang, dan laki-laki lebih agresif dan lebih besar kemungkinannya dari perempuan dalam memiliki pengharapan untuk sukses, tetapi perbedaan ini kecil adanya. Kita mengasumsikan bahwa tidak ada perbedaan berarti dalam produktivitas pekerjaan antara laki-laki dan perempuan (Robbins, 1996).

\section{Hubungan Lama Pengalaman Kerja dengan Kesiapsiagaan Tenaga Kesehatan Puskesmas}

Dari hasil penelitian ini menunjukkan proporsi terbesar ada pada kelompok responden dengan pengalaman kerja 6-15 tahun sebesar $67,5 \%$. Berikutnya pada lama pengalaman kerja $>16$ tahun proporsinya sebesar $30 \%$ dan kelompok dengan pengalaman kerja $<5$ tahun sebesar 2,5\%. Berdasarkan tabel 5.12 tampak bahwa proporsi kesiapsiagaan tenaga kesehatan puskesmas lebih tinggi pada responden dengan pengalaman kerja 6-15 tahun sebesar $62,5 \%$ dibandingkan dengan kelompok lama pengalaman kerja > 16 tahun proporsinya sebesar $27,5 \%$ dan kelompok dengan pengalaman kerja $<5$ tahun sebesar 2,5\% Dari hasil analisis statistik, tidak menunjukkan adanya perbedaan yang bermakna proporsi kesiapsiagaan menurut faktor lama pengalaman kerja tidak bermakna secara 
statistik dimana $p$ value $=0,572$ atau $p>$ 0,05 .

Hasil penelitian ini bisa saja terjadi mengingat bahwa pengalaman kerja keseluruhan dari masa kerja yang dijalani mungkin saja lebih berperan secara dominan dalam mendukung kesiapsiagaan tenaga kesehatan. Walaupun pengalaman akan membentuk perilaku petugas (Siagian, 1992), tetapi bukan berarti bahwa pengalaman yang telah dimiliki oleh petugas selalu dapat dipergunakan untuk melaksanakan tugas. Hal ini karena selalu dipengaruhi oleh perubahan-perubahan dan perkembangan yang selalu terjadi.

\section{Hubungan Frekuensi Pelatihan Manajemen Bencana dengan Kesiapsiagaan Tenaga Kesehatan Puskesmas}

Dari hasil penelitian ini menunjukkan bahwa kesiapsiagaan tenaga kesehatan puskesmas yang bekerja terkait dengan penanggulangan bencana banjir di kecamatan Manggala kota Makassar tahun 2019 proporsi terbesar ada pada kelompok responden yang pernah mengikuti pelatihan manajemen bencana 92,5\%. Kemudian yang tidak pernah mengikuti pelatihan sebesar 7,5\%. Berdasarkan tabel 5.12 tampak bahwa proporsi kesiapsiagaan tenaga kesehatan puskesmas lebih tinggi pada responden yang pernah mengikuti pelatihan manajemen bencana sebesar 25\% dibandingkan dengan kelompok yang tidak pernah mengikuti pelatihan sebesar $0 \%$ Dari hasil analisis statistik, ternyata tidak menunjukkan adanya perbedaan yang bermakna proporsi kesiapsiagaan menurut faktor pelatihan manajemen bencana tidak bermakna secara statistik dimana $p$ value $=$ 1,081 atau $p>0,05$.

Hasil penelitian ini tidak sejalan dengan Hasibuan (2008), yang menyatakan bahwa pelatihan merupakan proses pengembangan untuk meningkatkan kualitas sumber daya manusia, karena melalui pelatihan, technical skill, human skill, dan managerial skillnya akan semakin baik.

\section{Hubungan Frekuensi Simulasi/Gladi dengan Kesiapsiagaan Tenaga Kesehatan Puskesmas}

Dari hasil penelitian ini proporsi terbesar ada pada kelompok responden yang tidak pernah mengikuti gladi/simulasi sebesar $62,5 \%$. Kemudian yang pernah mengikuti gladi/simulasi sebesar $37,5 \%$.
Berdasarkan tabel 5.12 tampak bahwa proporsi kesiapsiagaan tenaga kesehatan puskesmas lebih tinggi pada responden yang tidak pernah mengikuti pelatihan gladi/simulasi sebesar $60 \%$ dibandingkan dengan kelompok yang pernah mengikuti gladi/simulasi sebesar $32,5 \%$ Dari hasil analisis statistik, ternyata tidak menunjukkan adanya perbedaan yang bermakna proporsi kesiapsiagaan menurut kelompok jenis kelamin tidak bermakna secara statistik dimana $p$ value $=1,177$ atau $p>0,05$.

Hasil ini dapat dijelaskan bahwa metode pelatihan dengan melakukan gladi/simulasi sepertinya tidak terlalu berperan dalam meningkatkan kesiapsiagaan tenaga kesehatan dalam penanggulangan bencana banjir. Menurut Andrew F. Sikula yang dikutip oleh Hasibuan (2008), menunjukkan adanya beberapa metode latihan yang dapat diberikan kepada pekerja tidak hanya dalam bentuk simulasi saja akan tetapi dapat berupa on the job, vestibule, demonstration dan example, apprenticeship dan classroom methods

\section{Hubungan Kecukupan Sarana dengan Kesiapsiagaan Tenaga Kesehatan Puskesmas}

Dari hasil penelitian ini proporsi terbesar ada pada kelompok responden yang menyatakan sarana yang tersedia cukup sebesar $65 \%$. Kemudian yang menyatakan tidak cukup sebesar 35\%. Berdasarkan tabel 5.12 tampak bahwa proporsi kesiapsiagaan tenaga kesehatan puskesmas lebih tinggi pada responden yang menyatakan sarana penanggulangan bencana di unit kerja cukup sebesar $57,5 \%$ dibandingkan dengan kelompok yang menyatakan tidak cukup sebesar 35\%. Dari hasil analisis statistik, ternyata tidak menunjukkan adanya perbedaan yang bermakna proporsi kesiapsiagaan menurut kecukupan sarana di unit kerja tidak bermakna secara statistik dimana $p$ value $=$ 1,746 atau $p>0,05$.

Sutermeister dalam kutipan Sedarmayanti (2009), menyatakan bahwa selain penyediaan sarana dan peralatan kerja yang lengkap juga harus mencakup dukungan organisasi yang baik, dukungan struktur organisasi, penyediaan teknologi, penyediaan tempat dan lingkungan kerja yang nyaman, penyediaan kondisi dan syarat kerja, peluang membangun hubungan kerja yang harmonis serta menyediakan kecukupan anggaran yang 
dibutuhkan untuk setiap pelaksanaan tugas akan meningkatkan produktivitas.

\section{Hubungan Tersedianya Biaya Operasional dengan Kesiapsiagaan Tenaga Kesehatan Puskesmas}

Dari hasil penelitian ini 9 proporsi terbesar ada pada kelompok responden yang menyatakan tidak tersedia biaya operasional sebesar $57,5 \%$. Kemudian yang menyatakan tersedia sebesar $42,5 \%$. Berdasarkan tabel 5.12 tampak bahwa proporsi kesiapsiagaan tenaga kesehatan puskesmas lebih tinggi pada responden yang menyatakan biaya operasional penanggulangan bencana di unit kerja tidak tersedia sebesar $50 \%$ dibandingkan dengan kelompok yang menyatakan tersedia sebesar $42,5 \%$. Dari hasil analisis statistik untuk melihat hubungan antara ketersediaan biaya operasional penanggulangan bencana di unit kerja dengan kesiapsiagaan ternyata tidak menunjukkan adanya perbedaan yang bermakna proporsi kesiapsiagaan menurut ketersediaan biaya operasional penanggulangan bencana diunit kerja tidak bermakna secara statistik dimana $p$ value $=$ 2,397 atau $p>0,05$.

Ini dapat dijelaskan bahwa ketersediaan biaya operasional untuk penanggulangan bencana banjir sepertinya tidak terlalu berperan dalam meningkatkan kesiapsiagaan tenaga kesehatan yang bersangkutan dalam penanggulangan bencana banjir. Hal ini bisa saja terjadi bahwa kesiapsiagaan tenaga kesehatan yang tergambar dalam produktivitas kerja tidak hanya dipengaruhi oleh ketersediaan biaya operasional di unit kerja.

\section{Hubungan Tersedianya Kebijakan Pemerintah dengan Kesiapsiagaan Tenaga Kesehatan Puskesmas}

Dari hasil penelitian ini proporsi terbesar ada pada kelompok responden yang menyatakan tidak tersedia kebijakan pemerintah sebesar $65 \%$. Kemudian yang menyatakan tersedia sebesar $35 \%$. Berdasarkan tabel 5.12 tampak bahwa proporsi kesiapsiagaan tenaga kesehatan puskesmas lebih tinggi pada responden yang menyatakan kebijakan pemerintah terkait penanggulangan bencana di unit kerja tidak tersedia sebesar $62,5 \%$ dibandingkan dengan kelompok yang menyatakan tersedia sebesar $30 \%$. Dari hasil analisis statistik, ternyata tidak menunjukkan adanya perbedaan yang bermakna proporsi kesiapsiagaan menurut ketersediaan kebijakan pemerintah terkait penanggulangan bencana di unit kerja tidak bermakna secara statistik dimana $p$ value $=$ 1,430 atau $p>0,05$.

Kebijakan terkait kesiapsiagaan bencana akan sangat berpengaruh karena merupakan upaya konkrit dalam pelaksanaan kegiatan kesiapsiagaan bencana yang meliputi pendidikan public, emergency planning, system peringatan dini, dan mobilisasi sumber daya. Dengan adanya kebijakan pemerintah maka akan mempermudah dalam penyusunan tim penanggulangan bencana, pengerahan sumber daya/tenaga kesehatan serta penggunaan sarana dan prasarana yang tersedia.

\section{Hubungan Tersedianya Protap/Pedoman dengan Kesiapsiagaan Tenaga Kesehatan Puskesmas}

Dari hasil penelitian ini proporsi terbesar ada pada kelompok responden yang menyatakan tersedia protap/pedoman sebesar $62,5 \%$. Kemudian yang menyatakan tidak tersedia sebesar $37,5 \%$. Berdasarkan tabel 5.12 tampak bahwa proporsi kesiapsiagaan tenaga kesehatan puskesmas lebih tinggi pada responden yang menyatakan protap/pedoman penanggulangan bencana di unit kerja tersedia sebesar $57,5 \%$ dibandingkan dengan kelompok yang menyatakan tidak tersedia sebesar $35 \%$. Dari hasil analisis statistik, ternyata menunjukkan adanya perbedaan yang bermakna proporsi kesiapsiagaan menurut ketersediaan protap/pedoman penanggulangan bencana di unit kerja bermakna secara statistik dimana $p$ value $=0,024$ atau $p<0,05$.

Hasil analisis ini bertentangan dengan Sinungan (2009), yang menyatakan bahwa tidak hanya dipengaruhi oleh modal (sarana, material, pembiayaan, dan lainlain) akan tetapi juga akan dipengaruhi oleh faktor tenaga kerja sendiri (kuantitas, pendidikan, keahlian, struktur pekerjaan, minat kerja, kemampuan, sikap, dan aspirasi), manajemen dan organisasi (kondisi kerja, iklim kerja, organisasi dan perencanaan, tatanan tugas, system insentif dan lain-lain). Selain itu dapat pula dikarenakan karena jumlah sampel yang ada masih belum dapat menjelaskan adanya perbedaan kesiapsiagaan tenaga 
kesehatan menurut ketersediaan protap/pedoman.

\section{Hubungan Pelaksanaan Evaluasi dengan Kesiapsiagaan Tenaga Kesehatan Puskesmas}

Dari hasil penelitian ini proporsi terbesar ada pada kelompok responden yang menyatakan dilakukan evaluasi sebesar 62,5\%. Kemudian yang menyatakan tidak dilakukan evaluasi sebesar $37,5 \%$. Berdasarkan tabel 5.12 tampak bahwa proporsi kesiapsiagaan tenaga kesehatan puskesmas lebih tinggi pada responden yang menyatakan dilakukan evaluasi setelah kegiatan penanggulangan bencana di unit kerja sebesar 57,5\% dibandingkan dengan kelompok yang menyatakan tidak dilakukan sebesar $35 \%$. Dari hasil analisis statistik, ternyata menunjukkan adanya perbedaan yang bermakna proporsi kesiapsiagaan menurut dilakukannya evaluasi setelah kegiatan penanggulangan bencana di unit kerja bermakna secara statistik dimana $p$ value $=0,024$ atau $p<0,05$.

Hasil dari penelitian ini sejalan dengan teori yang menyatakan bahwa evaluasi merupakan upaya perbaikan terhadap kegiatan yang telah dilaksanakan yang dihadapkan kepada tuntutan yang berubah baik secara internal maupun eksternal. Hasil ini sesuai dengan etos kerja terkait dengan peningkatan produktivitas (Sutrisno, 2009).

\section{Analisis Multivariat Faktor Kesiapsiagaan Tenaga Kesehatan Puskesmas}

Hasil dari analisis multivariat yang dilakukan menunjukkan bahwa kedua variabel mempunyai pengaruh yang sama terhadap kesiapsiagaan tenaga kesehatan puskesmas. Untuk hasil analisis multivariat faktor protap/pedoman, didapatkan bahwa faktor ini berpengaruh terhadap kesiapsiagaan tenaga kesehatan. Hasil analisis ini bertentangan dengan Sinungan (2009), yang menyatakan bahwa tidak hanya dipengaruhi oleh modal (sarana, material, pembiayaan, dan lain-lain) akan tetapi juga akan dipengaruhi oleh faktor tenaga kerja sendiri (kuantitas, pendidikan, keahlian, struktur pekerjaan, minat kerja, kemampuan, sikap, dan aspirasi), manajemen dan organisasi (kondisi kerja, iklim kerja, organisasi dan perencanaan, tatanan tugas, sistem insentif dan lain-lain).
Sementara faktor pelaksanaan evaluasi menunjukkan adanya hubungan yang bermakna dengan kesiapsiagaan tenaga kesehatan. Hal ini bermakna bahwa untuk meningkatkan kesiapsiagaan bencana tenaga kesehatan puskesmas akan lebih baik jika dilakukan kegiatan evaluasi terhadap diri tenaga kesehatan sendiri maupun pelaksanaan kegiatannya. Dengan melaksanakan evaluasi kita dapat mengukur keberhasilan upaya-upaya dan program yang dilakukan atau kegiatan penanggulangan yang dilaksanakan (Depkes, 2007).

\section{KESIMPULAN}

Dari hasil dan pembahasan penelitian ini, maka dapat ditarik kesimpulan sebagai berikut ini :

1. Gambaran kesiapsiagaan tenaga kesehatan puskesmas di kecamatan Manggala kota Makassar adalah sebesar $92,5 \%$.

2. Secara keseluruhan hanya terdapat dua faktor yang berhubungan dengan kesiapsiagaan tenaga kesehatan puskesmas dalam penanggulangan bencana banjir di kecamatan manggala kota Makassar tahun 2019 yaitu tersedianya protap/pedoman bencana dan pelaksanaan evaluasi.

\section{DAFTAR PUSTAKA}

A.A. Gde, Muninjaya, 2018. Manajemen Kesehatan. Penerbit Buku Kedokteran EGC: Jakarta

Adiyoso, W. 2018. Manajemen Bencana. Bumi Aksara: Jakarta

Arikunto,S. 2002. Prosedur Penelitian Suatu Pendekatan Praktek (edisi revisi ke- 5). Rineka Cipta: Jakarta

Dewi, R.N. 2010. Kesiapsiagaan Sumber Daya Kesehatan Dalam Penanggulangan Masalah Kesehatan Akibat Bencana Banjir di Provinsi DKI Jakarta.Tesis Fakultas Kesehatan Masyarakat Program Pasca Sarjana Universitas Indonesia Depok.

Djafar, M., Mastu, F, \& Patellongi, I. 2012. Pengaruh Penyuluhan Tentang Kesiapsiagaan Bencana Banjir Terhadap Pengetahuan dan Sikap Kepala Keluarga di Romang Tangngayya Kelurahan Tamangngapa Kecamatan Manggala Kota Makassar. Tesis 
Sekolah Pascasarjana Universitas Hasanuddin Makassar.

Endang, S.S. 2014. Manajemen Kesehatan: Teori dan Praktik di Puskesmas. Gajah Mada University Press: Yogyakarta

Handoko, R. 2013. Statistik Kesehatan. Mitra Cendikia Press: Yogyakarta

Hasibuan, Malayu SP, 2018. Manajemen Personalia dan Sumber Daya Manusia. Bumi Aksara: Jakarta

Heni, T. 2018. Perencanaan Program Promosi Kesehatan. Penerbit Andi: Yogyakarta

Kasmir, 2018. Manajemen Sumber Daya Manusia. Rajawali Pers: Depok

Nurdin, P. 2016. Menurunkan Risiko Bencana. Masagena Perss: Makassar

Nursalam,2013. Konsep dan Metodologi Penelitian IImu Keperawatan: Pedoman Skripsi, Tesis, dan Instrument Keperawatan, Salemba Medika: Jakarta

Pusponegoro, A.D. 2011. The Silent Disaster Bencana, dan Korban Massal. Sagung Seto: Jakarta

Sedarmayanti, 2009. Sumber Daya Manusia dan Produktivitas Kerja. Cetakan ketiga. CV. Mandar Maju: Bandung

Sabarguna, Boy, 2008. Manajemen Kinerja Pelayanan Rumah Sakit. CV. Sagung Seto: Jakarta

Saharullah, 2015. Hubungan Pengetahuan, Sikap dan Tindakan
Masyarakat Terhadap

Kesiapsiagaan Bencana Akibat

Banjir di Kecamatan Tempe

Kabupaten Wajo.Tesis Sekolah

Pasca Sarjana Universitas

Hasanuddin Makassar.

Samsuddin, Sadili, 2006. Manajemen Sumber Daya Manusia. Pustaka Setia: Bandung

Saryono, 2011. Metodologi Penelitian Kesehatan. Mitra Cendekia Press: Yogyakarta

Sugiyono, 2017. Metode Penelitian Kuantitatif, Kualitatif, dan R\&D. Alfabeta: Bandung

Sugiyono, 2017.Memahami Penelitian Kualitatif. Alfabeta: Bandung

Sulastomo, 2000. Manajemen Kesehatan. PT Gramedia Pustaka Umum: Jakarta

Undang-Undang Republik Indonesia Nomor 24 Tahun 2007 tentang Penanggulangan Bencana.

Uyanto, S.S. 2009. Pedoman Analisis Data dengan SPSS.Graha ilmu: Yogyakarta

Wijono,Djoko, 2001. Manajemen Mutu Pelayanan Kesehatan. Airlangga University Press: Surabaya

Winardi, 2007. Motivasi dan Pemotivasian dalam Manajemen. Rajawali Pers: Jakarta

Yuniarsih, T. 2008. Manajemen Sumber Daya Manusia. Alfabeta: Bandung 
Tabel 5.1

Distribusi Kesiapsiagaan Responden

$$
n=40
$$

\begin{tabular}{clcc}
\hline No & Kesiapsiagaan & $\mathbf{n}$ & $\mathbf{\%}$ \\
\hline 1 & Tidak siap siaga & 3 & 7.5 \\
2 & Siap siaga & 37 & 92.5 \\
\hline
\end{tabular}

Tabel 5.2

Distribusi Umur Responden

$$
\mathrm{n}=40
$$

\begin{tabular}{rcc}
\hline Umur & $\mathbf{n}$ & \% \\
\hline 19-34 tahun & 11 & 27.5 \\
35-60 tahun & 29 & 72.5 \\
\hline
\end{tabular}

Tabel 5.3

Distribusi Jenis Kelamin Responden

$n=40$

\begin{tabular}{lcc}
\hline \multicolumn{1}{c}{ Jenis Kelamin } & $\mathbf{n}$ & $\%$ \\
\hline Laki-laki & 6 & 15 \\
Perempuan & 34 & 85 \\
\hline
\end{tabular}

Tabel 5.4

Distribusi Lama Pengalaman Kerja Responden

$$
n=40
$$

\begin{tabular}{lcc}
\hline Masa kerja & $\mathbf{n}$ & $\mathbf{\%}$ \\
\hline kurang 5 tahun & 1 & 2.5 \\
$6-15$ tahun & 27 & 67.5 \\
lebih 16 tahun & 12 & 30 \\
\hline
\end{tabular}

Tabel 5.5

Distribusi Frekuensi Pelatihan Bencana Responden

$$
n=40
$$

\begin{tabular}{lcc}
\hline \multicolumn{1}{c}{ Frekuensi pelatihan } & $\mathbf{n}$ & \% \\
\hline Tidak pernah & 30 & 75 \\
Pernah & 10 & 25
\end{tabular}


Tabel 5.6

Distribusi Frekuensi Simulasi/Gladi Responden

$$
n=40
$$

\begin{tabular}{lcc}
\hline frekuensi & $\mathbf{n}$ & \% \\
\hline tidak pernah & 25 & 62.5 \\
Pernah & 15 & 37.5 \\
\hline
\end{tabular}

Tabel 5.7

Distribusi Kecukupan Sarana Menurut Responden

$n=40$

\begin{tabular}{lcc}
\hline \multicolumn{1}{c}{ Kecukupan Sarana } & $\mathbf{n}$ & \% \\
\hline tidak cukup & 14 & 35 \\
Cukup & 26 & 65 \\
\hline
\end{tabular}

Tabel 5.8

Distribusi Tersedianya Biaya Operasional Menurut Responden

$\mathrm{n}=40$

\begin{tabular}{lcc}
\hline \multicolumn{1}{c}{ Biaya operasional } & $\mathbf{n}$ & \% \\
\hline tidak tersedia & 23 & 57.5 \\
Tersedia & 17 & 42.5 \\
\hline
\end{tabular}

Tabel 5.9

Distribusi Tersedianya Kebijakan Pemerintah Tentang Kesiapsiagaan Bencana

$$
n=40
$$

\begin{tabular}{lcc}
\hline \multicolumn{1}{c}{ Kebijakan pemerintah } & $\mathbf{n}$ & $\mathbf{\%}$ \\
\hline Tidak tersedia & 26 & 65 \\
Tersedia & 14 & 35 \\
\hline
\end{tabular}

Tabel 5.10

Distribusi Tersedianya Protap/Pedoman Menurut

Responden

$$
n=40
$$

\begin{tabular}{lcc}
\hline \multicolumn{1}{c}{ Protap/ pedoman } & $\mathbf{n}$ & \% \\
\hline tidak tersedia & 15 & 37.5 \\
Tersedia & 25 & 62.5 \\
\hline
\end{tabular}


Tabel 5.11

Distribusi Pelaksanaan Evaluasi Kepada Responden

$$
n=40
$$

\begin{tabular}{lcc}
\hline Evaluasi & $\mathbf{n}$ & \% \\
\hline tidak dilakukan & 15 & 37.5 \\
Dilakukan & 25 & 62.5 \\
\hline
\end{tabular}

Tabel 5.12

Faktor Yang Berhubungan dengan Kesiapsiagaan Tenaga Kesehatan Puskesmas

\begin{tabular}{|c|c|c|c|c|c|c|}
\hline \multirow{2}{*}{ Faktor } & \multicolumn{2}{|c|}{ tidak siap siaga } & \multicolumn{2}{|c|}{ siap siaga } & \multirow{2}{*}{ total } & \multirow{2}{*}{ p value } \\
\hline & $\mathbf{n}$ & $\%$ & $\mathbf{n}$ & $\%$ & & \\
\hline Umur & & & & & & 1,230 \\
\hline 19-34 tahun & 0 & 0 & 11 & 27,5 & 11 & \\
\hline 35-60 tahun & 3 & 7,5 & 26 & 65 & 29 & \\
\hline jenis kelamin & & & & & & 0,572 \\
\hline Laki-laki & 0 & 0 & 6 & 15 & 6 & \\
\hline Perempuan & 3 & 7,5 & 31 & 77,5 & 34 & \\
\hline pengalaman kerja & & & & & & 0,093 \\
\hline kurang 5 tahun & 0 & 0 & 1 & 2,5 & 1 & \\
\hline $6-15$ tahun & 2 & 5 & 25 & 62,5 & 27 & \\
\hline lebih 16 tahun & 1 & 2,5 & 11 & 27,5 & 12 & \\
\hline frekuensi pelatihan & & & & & & 1,081 \\
\hline tidak pernah & 3 & 7,5 & 0 & 0 & 3 & \\
\hline Pernah & 27 & 67,5 & 10 & 25 & 37 & \\
\hline frekuensi simulasi & & & & & & 1,177 \\
\hline tidak pernah & 1 & 2,5 & 24 & 60 & 25 & \\
\hline Pernah & 2 & 5 & 13 & 32,5 & 15 & \\
\hline kecukupan sarana & & & & & & 1,746 \\
\hline tidak cukup & 0 & 0 & 14 & 35 & 14 & \\
\hline Cukup & 3 & 7,5 & 23 & 57,5 & 26 & \\
\hline biaya operasional & & & & & & 2,397 \\
\hline tidak tersedia & 3 & 7,5 & 20 & 50 & 23 & \\
\hline Tersedia & 0 & 0 & 17 & 42,5 & 17 & \\
\hline kebijakan pemerintah & & & & & & 1,430 \\
\hline tidak tersedia & 1 & 2,5 & 25 & 62,5 & 26 & \\
\hline Tersedia & 2 & 5 & 12 & 30 & 14 & \\
\hline
\end{tabular}


protap/pedoman

tidak tersedia

Tersedia

2

$$
23
$$

Evaluasi

tidak dilakukan

Dilakukan

1

2,5

5

14

23

57,5

$\begin{array}{cr}35 & 15 \\ 57,5 & 25\end{array}$

Tabel 5.13

Hasil uji regresi logistik variabel yang berpengaruh terhadap kesiapsiagaan tenaga kesehatan puskesmas dalam menghadapi bencana banjir tahun 2019

\begin{tabular}{|c|c|c|c|c|c|c|c|c|}
\hline \multirow[t]{2}{*}{ Variabel } & \multirow[t]{2}{*}{ B } & \multirow[t]{2}{*}{ S.E. } & \multirow[t]{2}{*}{ Wald } & \multirow[t]{2}{*}{$d f$} & \multirow[t]{2}{*}{ Sig. } & \multirow[t]{2}{*}{$\operatorname{Exp}(B)$} & \multicolumn{2}{|c|}{$\begin{array}{c}95 \% \text { C.I.for } \\
\text { EXP(B) }\end{array}$} \\
\hline & & & & & & & Lower & Upper \\
\hline $\begin{array}{l}\text { Protap } \\
\text { Bencana }\end{array}$ & -0.117 & 1.719 & 0.005 & 1 & 0.946 & 0.889 & 0.031 & 25.844 \\
\hline $\begin{array}{l}\text { Pelaksanaan } \\
\text { Evaluasi }\end{array}$ & -0.117 & 1.719 & 0.005 & 1 & 0.946 & 0.889 & 0.031 & 25.844 \\
\hline Constant & 2.898 & 2.388 & 1.473 & 1 & 0.225 & 18.140 & & \\
\hline
\end{tabular}

